\title{
EMERGING HORIZONS OF SCIENCE IN FISHERIES
}

\author{
R. JAIN ${ }^{1 *} \&$ R. SAO ${ }^{2}$ \\ ${ }^{1}$ Department of Zoology, Loyola College, Kunkuri, CG, India \\ ${ }^{2}$ Department. of Zoology, G. E. R. P.G. SC. College, Bilaspur, CG, India
}

\section{ABSTRACT}

Unbalanced fishing and overexploitation of water ecosystem have led to the quantitative and qualitative destruction of fishes. This concern is a major threat to fish life causing adverse reproductive, population, growth, physiological, genetic effects etc. however advancement of rapid technological developments provide various techniques which are being used for understanding, monitoring and protecting fish populations. For example, micro-chemical analyses of both otoliths and other calcified structures in fishes are widely used as valuable tools for understanding the age structures, life histories, habitat use, migration routes and dietary patterns of many fish populations and have contributed significantly to population management and conservation over time.

Emerging science has introduced many new techniques like genetic sequencing technologies. Through this technology now one can determine the cause for population variation of many fish species under different environmental stress and gather the knowledge of evolutionary and adaptive physiology which can be known through generating and interpreting sequence information. For example population of fish living in mental contaminated river varies from the normal river. Further, DNA bar-coding now allows global tracking of seafood. Use of eDNA is arguably on the verge of revolutionizing fish community monitoring and is becoming an effective tool for monitoring the health of aquatic ecosystem. Major progress has been made in advanced modelling techniques, to understand the effects of environmental change on fishes at population and community levels including multiple trophic levels. For example, developments in computing and software have allowed for a range of food-web models, such as Ecopath. The modelling techniques provide information's of population dynamics including energy budgets, reproduction, larval dispersal, genetic changes and productivity of fisheries, leading to improved utility for management and conservation. Conventional trawl consumes more fuel and causes extensive damage to the benthic zone, to solve such problem an alternative has been developed using laser technique by which target species are herded with direct laser beams leaving non-target species undisturbed with substantially reducing the volume of fossil fuel used per catch.

We can say that with new approaches of advancing scientific tools and techniques there has been immense modification in the field of fish management which has ultimately reduced the potential threats to some extent.

KEYWORDS: Emerging horizon, Otoliths, eDNA and Ecopath

Received: Dec 17, 2020; Accepted: Jan 07, 2021; Published: Jan 27, 2021; Paper Id.: IJZRJUN20211

\section{INTRODUCTION}

In recent years many disruptive technologies are introduced in fisheries management through which real time safe fishing is trying to acquire. Strategy is clear, that better you see better you will manage. New information and monitoring technologies are potential game changers for fisheries management and can be of help in achieving green growth of the sector. Application of new technologies has allowed governments to collect more data on fish 
stocks, better monitor, enforce and evaluate the environmental impacts of fisheries activities and improve the effectiveness of policies to sustainably manage fisheries. Other like micro analysis of otoliths of fishes has been improved into better tool. Modelling techniques such as Ecopath enable us to better understanding of the water ecosystem, traditional techniques to catch fishes consumes a lot of fuel as well as pollution in the water bodies which are being used to catch fishes as per thinking about the industrial scale and commercial level they use large ships for long time on the sea causes also disturbance in the ecosystem there.Laser beam technique to catch fishes can be the alternative technique with no harm causing side effect, with less fuel consumption.

According to an analysis of emerging horizon there are many emerging factors are being considered in all field among them use of eDNA for surveillance and monitoring, gene drives and autocidal control, changing agriculture practice are biotechnological issues are in the list. Among them technologies related to gene and DNA are on the top concern.

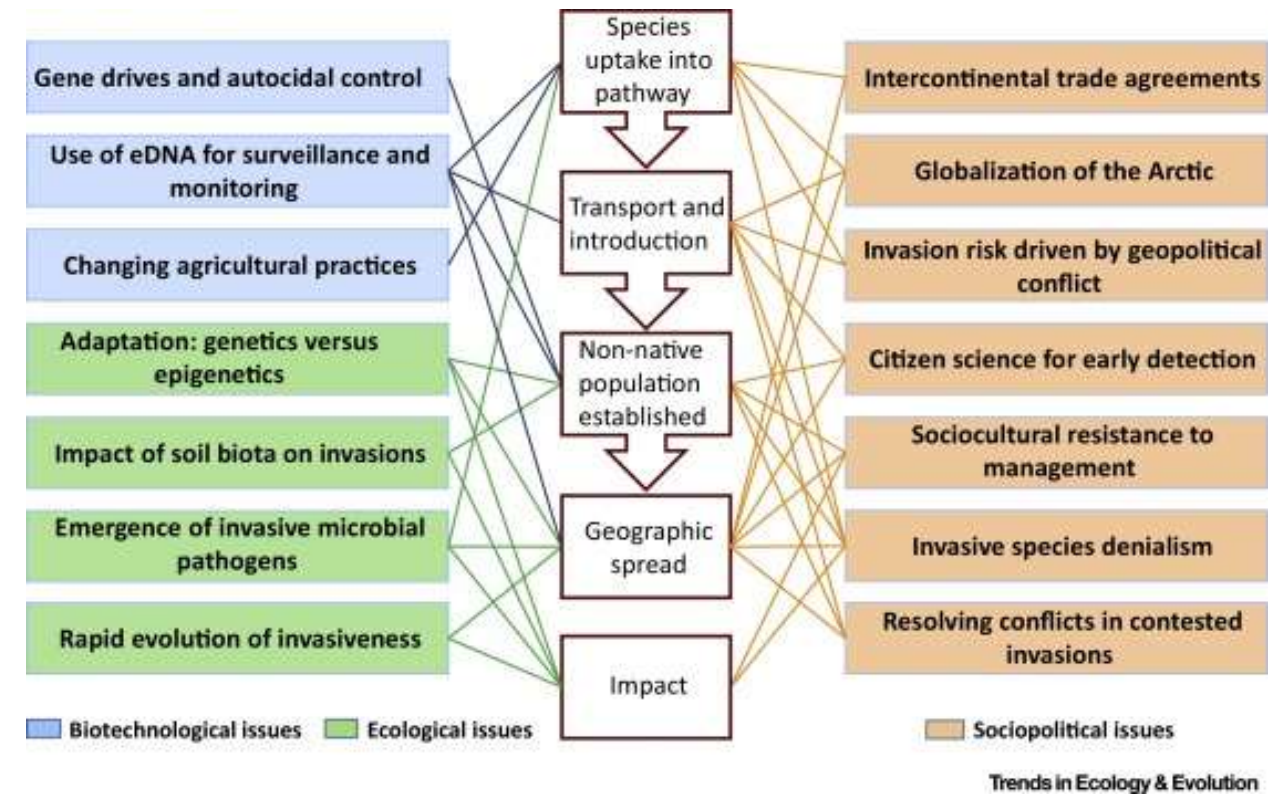

\section{MATERIAL AND METHODS}

\section{Micro Chemical Analysis of otoliths and Calcified structure}

Otolith and calcified structure of fishes are that kind of structures and part of fish which are not easily deteriorate or destroyed even after the death of fish. So they are subjected to get some information about the fish they belong. By micro chemical analysis of otolith and calcified structures we are able to get information like their age structure, life history, habitat use, migration routes, and dietary pattern of many fish population. These are the very important information about fish so that industries can produce fishes in large quantity growing them by giving them the best care with budget in natural way for better quality production.

- In developed countries were using this technique for 3 decades.

- In under developing countries it arises as a useful technique.

- Including in industrial interest it becomes a useful tool.

\section{Genetic sequencing techniques (eDNA):}

It is a quite useful technique to know about the ecology of certain ecosystem. The sediments and water sample of water 
body contains remaining of living organism present in that ecosystem. So,after taking the sample,theyisolate DNA of the organism. And then makethe eDNA as record. In the whole process no organism in living condition is involved, so practically it does not harmany creature in water body. Further this eDNA used for tracking of many aquatic species.

- This technique requires very much cleaning to avoid unwanted contamination in sample.

- They extract eDNA sample from sediments, water samples.

- There is no ethical issue with this technique because there is no using of living organism as sample.

\section{Modelling Techniques (Software):}

Ecopath with Ecosim (EwE) is a free and open source ecosystem modelling software suite. Initially started at NOAA by Jeffrey, Polovina but has been developed at the formerly UBC fisheries center of the Universities of British Columbia.

EwE has three main components:

- Ecopath - a static, mass - balanced snapshot of the ecosystem.

- Ecosim - a time dynamic simulation module for policy exploration

- Ecospace - a spatial and temporal dynamic module designed for exploring the combined

- Impact of fishing, the placement of protected areas and changing environmental condition.

- There issoftware to understand better the ecosystem.

- Helps with food chain and food web better understanding along with popular dynamics energy budgets, reproduction, larval dispersal, genetic change and fisheries production and productivity information.

- It enhancing its version.

- Initial it was launched in 2007. Now it is better in many ways.

\section{Using Laser Technology in Catching Fish:}

It is a quite useful technique. In which we can catch only the targeted fishes. In this kind of technology we project the laser of certain frequency and for a particular range of frequency a particular fish species shows particular response. By using this behavioural response we catch only targeted species, since other species not shows any response towards a certain frequency they don't lure into the net.

- In European countries ithas gain much popularity. And accepted as a good technique.

- Which catches only target fishes.

- Fishes attracted towards it and come in net by them self.

- Hence this technique ensures no harm to non-targetspecies in ecosystem.

- This also required very less full as compared to conventional trawling techniques.

\section{RESULT AND DISCUSSIONS}

Micro chemical analysis, eDNA, modelling techniques are seems to beno harm or less harm causing techniques, to better understanding and analysis process. If we look on the micro chemical analysis of otolith and calcified structure of fish as far there is no such problem with it but regarding eDNA it can be degrade rapidly factors such as temperature, alkalinity and trophic state affect its stability. eDNA techniques and process needs very carefulhandling of sample and many time cleaning and changing of gloves after each step to avoiddamage or any contamination of other DNA in collected sample 
which needs a high tech lab. So many be it can't be used in many under developing countries.

But techniques like laser using trawling technologies may non- affectnon-targetspecies. But with less consumption of fuel it can lead to overexploitation without any potential monitoring techniques.Regarding effectiveness of laser there are some factors which we also should consider for fish behaviour, the issue remains that will laser be visible to fish, which are they likely to react either by avoiding or being attracted to the light. Preliminary tank experiments using a laser stripe system developed at Cranfield University to image groups of live haddock and whiting indicating that the fish were aware of and often attempted to avoid the swath of laser light.

Along being harmless these new technologies also supposed to be cost effective, more functional, and more effective than the other traditional techniques. Only then they can be accepted in place of the old harm causing techniques. This can be only finding out by the time, as we face problems onward.

\section{ACKNOWLEDGEMENT}

I owe my great many thanks to Dr. Rashmi Sao (Prof. of Zoology) Govt. E. Raghvendra Rao P.G. Science College, Bilaspur (C.G.) for her abundant support, appreciation and Valuable guidance with her imaginative \& innovative ideas thus making this paper work a thing of excitement and joy.

I also want to thanks Miss Anupam Minj and Miss Ansi Kesar Lakra for his various intellectual and moral supports.

\section{CONCLUSIONS}

For sure these new techniques are introduced to enhancethe process to overcome problem but still it is not appropriate to say these techniques are $100 \%$ sure safe and will not lead to any harmful misuse. Because we still don't know what kind of new problems can be arise with them and low much potential they are to causing them. If there is considerable evidence, an issue is no longer novel.

\section{REFERENCES}

1. Clark, C.W. (1985), Bioeconomic Modelling and Fisheries Management, John Wiley and Sons, New York.

2. Rajasenan, D (1987), "Management of Externalities of Trawl Fisheries in Kerala", Indian Manager, Vol. XVI, No. 2, AprilJune. Rajasenan,

3. Ujjania, N. C., and NANDITA SONI. "Estimation of theoretical harvestable size of Indian major carps in Vallabh Sagar reservoir, Gujarat (India)." International Journal of Applied and Natural Science 6.4 (2017): 175-180.

4. Tetlow S., Allwood R.L. (1995), Development and application of a novel underwater laser illumination system, Underwater Technology, vol.212 (pg. 13-20)

5. Charles Anthony, T (2001), "Sustainable Fishery Systems, Fish and Aquatic Resources", Series 5, Blackwell Science.

6. Bhondve, A. M. I. T., et al. "Assessment of job satisfaction among fishermen in southern-east costal area of mumbai, India." General Med 2 (2013): 65-74.

7. McGoodwin JR (2001), Understanding the cultures of fishing communities. A key to fisheries management and food security FAO Fisheries, technical paper 401. 
8. Froese, $R$ and $K$ Kenser-Reyes (2002), Impact of Fishing on the Abundance of Marine Species International Council for the Exploration of the Sea.

9. N.Graham, E.G. Jones, D.G. Reid (2004), Review of technological advances for study of fish behaviour in relation to demersal fishing trawls.

10. Chandra, S. A. T. I. S. H., N. E. E. L. A. M. Yadav, and A. M. Saxena. "An ecological aspect on digenetic trematode parasite of fresh water fishes from Uttar Pradesh (India)." Int J Appl Nat Sci 5.4 (2016): 93-102.

11. Morgan, Gary; staples, Derek and Funge- Smith (2007), Fishing capacity management and illegal, unreported and unregulated fishing in Asia FAO RAP Publication.

12. Duffy, J. Emmett (2008), Marine biodiversity and food security Encyclopedia of Earth.

13. Atici, T. A. H. I. R., and M. A. S. O. U. M. E. H. Shams. "Most abundance Diatom Taxa of rivers in Turkey and Iran." International Journal of Botany and Research (IJBR) 7.5 (2017): 9-14.

14. Dejean T, Valentini A, Duparc A, Pellier-Cut S, Pompanon F, Taberlet P et al. (2011), Persistence of environmental DNAin freshwater ecosystems. PLoS One. Doi:10.1371/journal.pone.0023398. pmid: 21858099

15. 2015, Global overview of the application of the Ecopath with ecoism modelling approach using the ecobase repositoryecological modelling 302:42.53.

16. 2016, Reviews in fisheries science and aquaculture.

17. Kanaga, V., and P. Sivasankar. "Fishermen constraints in marine fisheries at Therespuram-an analysis." International Journal of Agricultural Science and Research (IJASR) 5.2 (2015): 105-109.

18. 2016, A review of the application of otoliths microchemistry toward the study of Latin American Fisher. DOl: $10.1080 / 23308249.1202189$

19. Deiner K, Bik HM, Machler E, Seymour M, Lacoursiere- Roussel A, Altermatt F, et al. (2017), Environmental DNA metabarcoding: Transforming how we survey animal communities. Mol Ecol. 26:5872- 5859. Doi: 10.1111/mec.14350. Pmid: 28921802

20. William J. Sutherland and Stuart H.M. Butchart (2018), A horizon scan of emerging issues of global conservation and biological diversity.

21. Kiran, B. R., and K. S. Murthy. "Watershed management and aquaculture in relation to fisheries." International Journal of Agricultural Science and Research (IJASR) 3.2 (2013): 155-174.

22. Moreno, M and Invanova NV (2019), Using eDNA to biomonitor the fish community in a tropical oligotrophic lake.

23. Tetlow S., Creaven S., Jones E.G., Raid D.G., laser stripe imaging to determine three dimensional information of fish shoals Underwater Technology (in Press) 
